\title{
Sustainable Smart Cities Challenges in Project Management Curriculum
}

\author{
Vered Holzmann \\ The Academic College of Tel Aviv Yaffo
}

Business schools aim to educate and train tomorrow's managers, who will be responsible to lead their organizations towards success. Since businesses use projects as the main means to implement innovative strategy in all industry domains, it is the responsibility of project management instructors not only to explain relevant concepts and introduce tools and techniques, but also to raise students' awareness to current and future social and environmental challenges and to offer methods to face those challenges. The paper presents case studies analysis to identify good practices for integrating challenges of sustainable cities and communities into the curriculum of project management courses.

Keywords: 21st century challenges, sustainability, smart cities and communities, project management, higher education

\section{INTRODUCTION}

In the current complex society, and especially nowadays following Covid-19, there is an increasing attention to the need for a more sustainable future for all (Eaton \& Heckscher, 2020). Sustainability is a broad concept that takes into consideration the relationship among economic development, environmental quality and social equity (Rogers et al., 2012). This paper adopts the theory of Munasinghe (1993) that includes three main approaches to sustainable development: economic approach, which refers to maximizing income while maintaining a constant or increase stock of capital; ecological approach, which refers to maintaining resilience and robustness of biological and physical systems; and social-cultural approach, which refers to maintaining stability of social and cultural systems. In light of the $21^{\text {st }}$ century challenges, projects play a crucial role, as they are the means to create a change in the social, ecological and business worlds through sustainable project products, project processes, and organizational commitment. Thus, companies seek ways to bring sustainability into projects and into project management practices, led by project managers who are aware to and trained for sustainability (Aarseth et al., 2017; Adriana \& Ioana-Maria, 2013; Marcelino-Sádaba et al., 2015; Silvius \& Schipper, 2014b). Based on the acknowledged understanding that universities have a dominant contribution to the development and training of future project managers (e.g. Ramazani \& Jergeas, 2015; Turner, 2016) as responsible managers who are committed to sustainability (Avelar et al., 2019), it is time for higher education institution to examine approaches to go beyond policy (Leal Filho et al., 2020) and to introduce sustainability challenges to the curriculum of project management.

The current paper examines two cases of project management courses for Master students in management programs. In each course, the students were asked to work in teams for the development of a new and innovative project idea that will contribute to sustainable smart cities and communities. This 
mission is stated in the UN Sustainable Development Goals (SDG), under Goal \#11, as "Make cities inclusive, safe, resilient and sustainable". The students had to collaborate with their teammates for the submission of an appropriate project plan. While the main assignment was similar in both groups, there were differences with regard to the particularity of the assignment and collaborating stakeholders. The final submissions were assessed by the educator and by external evaluators on several criteria including value of the solution, level innovativeness, adherence to project management methodologies, and utilization of project management tools and techniques. In addition, the students were asked to reflect on the experience concerning the learning process, the benefits and drawbacks, and implication for future actions. The case studies analysis provides an empirical ground for insights on effectively introducing sustainability challenges to project management graduate students.

This paper starts with a brief review of project management education in higher education and previous attempts to integrate sustainability concepts into the curriculum, in order to provide background context for the paper. Next, it describes two case studies in which graduate management students in two different institutions experienced the need to respond to sustainability challenges by developing relevant project plans. The results as well as the students' reflections on the process are analyzed. Finally, conclusions are discussed and recommendations are presented.

\section{PROJECT MANAGEMENT \& SUSTAINABILITY IN HIGHER EDUCATION}

In modern businesses, project management plays a central role to implement strategy through innovative processes that create valuable outcomes and outputs. Therefore, in recent years, project management education has receives an increased attention (Egginton, 2012; Ramazani \& Jergeas, 2015; Svejvig \& Andersen, 2015; Thomas \& Mengel, 2008; Turner, 2016). Several studies have examined different teaching and learning methods, including game-based learning, interactive learning, and virtual learning utilities (Ashleigh et al., 2012; Hussein, 2015; Shelley, 2015), while other studies have discussed the need to expand the content of project management academic courses form the basic "iron triangle" (scope, schedule, budget) to additional aspects of project managers' skills and competencies such as leadership, critical thinking, problem solving, and communication (Mengel, 2008; Ojiako et al., 2011; Turner, 2016).

Literature review reveals that the topic of sustainability has received a lot of research attention in the last few years, especially in the context of education on the Sustainable Development Goals (SDGs) (Avelar et al., 2019). One of the prominent works in this field, suggests that introducing sustainability to undergraduate and graduate students can be achieved in numerous diverse perspectives, including education about sustainability, education for sustainability, and institutional support for sustainability (Sterling, 2004). Although there are strong linkages between institutions' commitment to sustainability and implementation in terms of strategies and policies, most efforts are not holistically integrated throughout the higher education system (Lozano et al., 2015). Figueiró and Raufflet (2015) present a systematic analysis of 78 articles published in international higher education and management education journals between 2003 and 2013. Analysis of the focus of those publications shows that 32 papers deal with introduction of sustainability in management education, and analysis of teaching techniques yielded the conclusion that teaching sustainability calls for "a shift from a classical teaching method towards a more interactive one in which students participate in the co-construction" (p.29).

Narrowing down the integration of sustainability from the overall higher education system into the domain of business schools and faculties of management, and more specifically into the field of project management, leads to insights on how this topic can be facilitated in different several ways on different levels. For example, Painter-Morland et al., (2016) presented a holistic view in which systemic institutional integration of sustainability in business and management schools should be applied. In addition to four different approaches to integrating sustainability into the curriculum, they defined a set of criteria for institutional commitment. Ardito et al., (2019) focused on the specific challenge of smart cities and the way universities can contribute to smart cities projects. The role of universities as knowledge gatekeepers, knowledge providers, and knowledge evaluators in the knowledge-based ecosystems was discussed. Sroufe 
and Ramos (2011) examined a model to incorporate sustainability consulting projects into MBA programs. Their case yielded successful sustainability projects, but it is worthwhile to mention that it was based on a comprehensive MBA program, where the project management course was only introduced through mini lectures. Cicmil and Gaggiotti (2018), on the other hand, offered a longstanding experience with designing and delivering a project management module for an MBA program to explore the concept of responsible project management education. They adopted a participatory pedagogic approach to a project management module that was delivered in a block of several consecutive days to MBA students. The authors discussed benefits and challenges related to responsible project management studies as a broad concept.

To summarize, the importance and relevance of sustainability challenges is well recognized in higher education institutions, and specifically in business schools. However, in most cases, the integration of sustainability remains on the strategic level of the institution while today - more than ever before following the global crisis triggered by Covid-19 there is a need to integrate sustainability into the curriculum. Keeping in mind the central role that projects and project managers play in the current business world, there is a need to study good practices of incorporating sustainability related issues into the specific academic curriculum of project management. The current paper aims to focus on this topic by describing two case studies of implementing integration of practical sustainability challenges in project management courses where students were asked to design and develop relevant project plans.

\section{SUSTAINABILITY CHALLENGES IN PROJECT MANAGEMENT COURSES}

An action research approach was applied in the current study with the purpose to "produce practical knowledge that is useful to people in the everyday conduct of their lives" (Reason \& Bradbury, 2001, p. 2). This method, which was previously used in the context of management education (Dehler \& Edmonds, 2006; Raelin \& Coghlan, 2006; Shelley, 2015), enables an interactive process of investigation that is translated into effective learning by providing students with the opportunity to work on actual relevant challenges. The following cases are based on a personal experience in project management courses that were delivered during 2019 fall semester in two different higher education institutions, in Italy and in Israel. for purpose of confidentiality the specific details of the universities and the programs will remain anonymous. In both courses, the students were asked to investigate the needs, define goals and objectives, and offer project plans that can be used as solutions to sustainable smart cities and communities. The main theme was UN Sustainable Development Goal (SDG) \#11 - Sustainable cities and communities: "Make cities inclusive, safe, resilient and sustainable".

FIGURE 1

UN SUSTAINABLE DEVELOPMENT GOAL 11

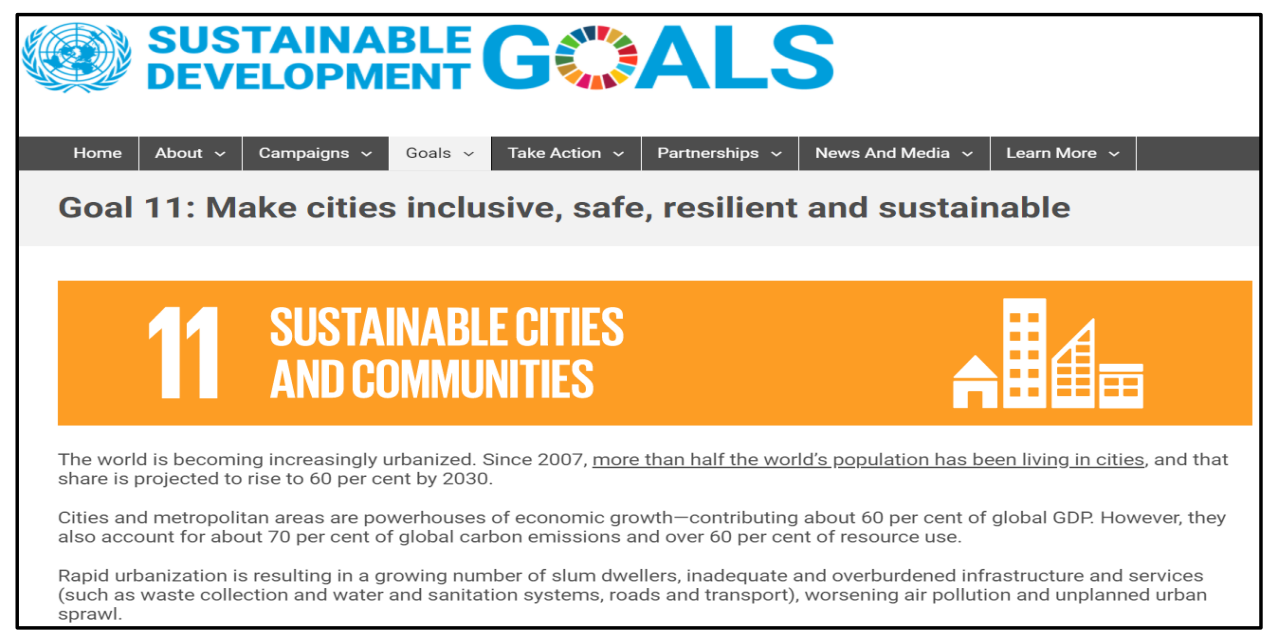

Source: https://www.un.org/sustainabledevelopment/cities/ 


\section{MSc Program in an Italian University}

Students for Master of Science in Management in a large university in Italy should select two, out of eight, elective courses on their second year of studies. In 2019, 40 students participated in the "project management" course. The overall course duration was four weeks with eight teaching hours every week. The learning objectives of the course were defined as follows: At the end of the course, students will be able to (1) identify and define needs to initiate a project; (2) understand and implement the project planning and management processes; (3) analyze managerial and leadership issues in the context of project management from different perspectives; and (4) examine and apply tools and techniques to effectively manage project teams. The course covered approaches, methodologies, tools and techniques to prepare team members, managers and leaders to participate in and lead successful projects in organizations. During the course, the students were taught the basics of innovation, project initiation, traditional and agile project management methodologies, project risk and communication planning and management.

For the main assignment, the students had to work in teams, composed of four or five students in each team, to initiate and prepare a project plan for the development of a new and innovative product or process for smart cities. The students had the whole course duration, i.e., four weeks to work on the project initiation and plans which was due at the end of the course for presentation. On the first day of the course, the students were briefly introduced, by the lecturer, to the concepts and challenges of smart cities. On the last day of classes, the students had to submit a final paper and to present in class their project idea and plan. The following table summarizes the projects that the teams have developed.

TABLE 1

\section{LIST OF PROJECTS BY ITALIAN STUDENT TEAMS}

\begin{tabular}{|c|l|l|l|}
\hline Team & Project Title & The need(s) / Opportunity & Product / Process \\
\hline $\mathbf{1}$ & $\begin{array}{l}\text { Improved safety in the } \\
\text { sea and ocean }\end{array}$ & $\begin{array}{l}\text { Keep beaches safe, improve control } \\
\text { over beachside, keep an eye on } \\
\text { pollution }\end{array}$ & $\begin{array}{l}\text { Drone boats with sensors to } \\
\text { place around the beachside }\end{array}$ \\
\hline $\mathbf{3}$ & $\begin{array}{l}\text { Targeted advertising in } \\
\text { public places }\end{array}$ & $\begin{array}{l}\text { Inform citizens on new initiatives, } \\
\text { based on personalization, while } \\
\text { following lawful use of data }\end{array}$ & $\begin{array}{l}\text { Real-time learning algorithm } \\
\text { to produce personalized } \\
\text { advertising }\end{array}$ \\
\hline $\mathbf{4}$ & $\begin{array}{l}\text { Promote municipal } \\
\text { energy efficiency }\end{array}$ & $\begin{array}{l}\text { Replate an efficient system to control } \\
\text { traffic and improve the quality of } \\
\text { transportation }\end{array}$ & $\begin{array}{l}\text { A computerized tourism } \\
\text { system for Venice } \\
\text { innovative technologies }\end{array}$ \\
\hline $\mathbf{5}$ & $\begin{array}{l}\text { Ecological city } \\
\text { transportation }\end{array}$ & $\begin{array}{l}\text { Decrease pollution and improve } \\
\text { transportation in cities }\end{array}$ & $\begin{array}{l}\text { Algorithm to coordinate } \\
\text { domestic energy grid and } \\
\text { electric vehicles }\end{array}$ \\
\hline $\mathbf{6}$ & $\begin{array}{l}\text { Improved healthcare } \\
\text { emergency system }\end{array}$ & $\begin{array}{l}\text { Optimize emergency intervention } \\
\text { by exploiting geo-technologies }\end{array}$ & $\begin{array}{l}\text { An App for emergen forgen } \\
\text { healthcare }\end{array}$ \\
\hline $\mathbf{7}$ & $\begin{array}{l}\text { Ecological-sustainable } \\
\text { plant }\end{array}$ & $\begin{array}{l}\text { Use green technologies to develop } \\
\text { new construction materials }\end{array}$ & $\begin{array}{l}\text { Ecological cement for the } \\
\text { construction industry }\end{array}$ \\
\hline $\mathbf{8}$ & $\begin{array}{l}\text { Improved citizens' } \\
\text { connectivity }\end{array}$ & $\begin{array}{l}\text { Create a sense of community by } \\
\text { advanced technologies }\end{array}$ & $\begin{array}{l}\text { An App to connect city } \\
\text { residents education }\end{array}$ \\
\hline $\mathbf{9}$ & $\begin{array}{l}\text { Improved public } \\
\text { transportation in cities }\end{array}$ & $\begin{array}{l}\text { Minimize time loss and increase } \\
\text { comfort using city transportation }\end{array}$ & $\begin{array}{l}\text { Gateways with face } \\
\text { recognition }\end{array}$ \\
\hline
\end{tabular}

As can be seen in the table above, the ideas that students highlighted in the process of developing new and innovative ideas for smart cities are related to traffic and public transportation, energy efficiency, ecology, and citizens' health, safety, and connectivity. In their papers, the student teams presented a strategic 
analysis of the customer organization and explained how the planned project is aligned with the organizational strategy. They identified the customer and prospective users as well as the need(s) or opportunity, defined the project's goals and objectives, and described the final product/process. Then, they presented the detailed project plan, accompanied by a risk management plan and a communication plan.

\section{MBA Program in an Israeli University}

Students for Master of Business Administration (MBA), who are specialized in Management of Technology and Information Systems, in the Faculty of Management in an Israeli University, are required to take "technological project management" course, which is also offered, as an elective course, for MBA students in other specializations. In 2019, 40 students attended this course, which included the same total number of contact hours but lasted 13 weeks, and the students were taught the same topics, i.e., basics of innovation, project initiation, traditional and agile project management methodologies, project risk and communication planning and management. Although the learning objectives were similar to the ones of the course that was delivered a month earlier in Italy, following the Italian students' feedback, several changes have been made to the experiential component in the course. The final teamwork assignment, conducted by teams of 4 students, to initiate and prepare a project plan for the development of a new and innovative product or process for sustainable smart cities, have remained the same. However, in this case, instead of presenting the challenges of sustainable and smart cities and communities by the instructor, a collaboration was made with the municipality of Tel Aviv Jaffa. At the first day of the course, the students were introduced, by a representative of the municipality, to the concepts and challenges related to sustainable smart cities and its implementation in the city of Tel Aviv. The external representative, who is an experienced entrepreneur working with the municipality, presented the long-term goals of the city which can be summarized as follows: to improve the well-being of the citizens through economic and cultural affairs, society and communities' belonging, efficient governance, and better urban environment. In addition, in a mid-term session, the students were invited to visit CityZone, which is an innovation lab open to individual entrepreneurs, local government officers, and corporates to advance solutions that address urban challenges. The lab provides an environment to develop, test and demo new technologies that meet challenges faced by urban areas, prior to a large scale implementation. On the last day of classes, the students had to submit a final paper and to present in class their project idea and plan. However, this time, they presented to panel of top managers from Tel Aviv Jaffa municipality, who provided immediate feedback. The following table summarizes the projects that the student teams had developed.

TABLE 2

\section{LIST OF PROJECTS BY ISRAELI STUDENT TEAMS}

\begin{tabular}{|c|l|l|l|}
\hline Team & Project Title & The need(s) / Opportunity & Product / Process \\
\hline $\mathbf{1}$ & $\begin{array}{l}\text { Improved access to } \\
\text { governmental offices }\end{array}$ & $\begin{array}{l}\text { Parking next to municipal offices is } \\
\text { expensive and rarely available }\end{array}$ & $\begin{array}{l}\text { A scheduling App match } \\
\text { meetings and parking }\end{array}$ \\
\hline $\mathbf{2}$ & Improve urban traffic & $\begin{array}{l}\text { Heavy traffic loads in the city and } \\
\text { plenty of waiting time }\end{array}$ & $\begin{array}{l}\text { Artificial intelligence system } \\
\text { for traffic lights }\end{array}$ \\
\hline $\mathbf{3}$ & $\begin{array}{l}\text { Increased safety of } \\
\text { scooter riders }\end{array}$ & $\begin{array}{l}\text { Fatal accidents could have been } \\
\text { prevented by helmets }\end{array}$ & $\begin{array}{l}\text { An integrated helmet in } \\
\text { shared motor scooters, } \\
\text { released by an App }\end{array}$ \\
\hline $\mathbf{4}$ & $\begin{array}{l}\text { Increased community } \\
\text { belonging and reuse of } \\
\text { products }\end{array}$ & $\begin{array}{l}\text { Citizens need different things at } \\
\text { different times, and don't want } \\
\text { (can) buy new products frequently }\end{array}$ & $\begin{array}{l}\text { A community network of } \\
\text { neighbors to share products } \\
\text { and services }\end{array}$ \\
\hline $\mathbf{5}$ & $\begin{array}{l}\text { Improved parking } \\
\text { facilitation }\end{array}$ & $\begin{array}{l}\text { Parking signs are complicated for } \\
\text { understanding }\end{array}$ & $\begin{array}{l}\text { City's maps supported with } \\
\text { free-to-use additional layer }\end{array}$ \\
\hline
\end{tabular}




\begin{tabular}{|c|l|l|l|}
\hline Team & Project Title & The need(s) / Opportunity & Product / Process \\
\hline $\mathbf{6}$ & $\begin{array}{l}\text { Improved recycling } \\
\text { facilities }\end{array}$ & $\begin{array}{l}\text { Passersby need to through garbage } \\
\text { in the appropriate containers for } \\
\text { recycling }\end{array}$ & $\begin{array}{l}\text { A feature on the city's App } \\
\text { to locate nearby recycling } \\
\text { container }\end{array}$ \\
\hline $\mathbf{7}$ & $\begin{array}{l}\text { Increased connectivity } \\
\text { among neighbors }\end{array}$ & $\begin{array}{l}\text { Unused facilities can be used by } \\
\text { citizen groups for hobbies }\end{array}$ & $\begin{array}{l}\text { A secured App for groups of } \\
\text { players (sport, music) }\end{array}$ \\
\hline $\mathbf{8}$ & $\begin{array}{l}\text { Improved safety of } \\
\text { kindergarten children }\end{array}$ & $\begin{array}{l}\text { Failure to monitor violence against } \\
\text { children in kindergartens }\end{array}$ & $\begin{array}{l}\text { AI monitoring system to } \\
\text { detect violence and inform } \\
\text { the authorities }\end{array}$ \\
\hline
\end{tabular}

In this course, the ideas that student teams highlighted were overall similar and referred to the issues of traffic, safety, recycling and connectivity. However, interestingly, even though the Israeli student teams have worked directly with a specific "customer", they were less concerned about the financial aspects of the suggested projects, comparing to the Italian student teams who did not have a "real customer".

\section{FEEDBACKS AND ASSESSMENT}

The following sections present different perspectives of the analysis of the two cases. Due to confidentiality reasons, not all the details are presented in this paper. However, the analysis results of the university official surveys are briefly described, also with comparison to previous year's assessments. In addition, the results of content analysis of the participating students' reflective summary are discussed.

\section{Official Students' Feedback Analysis}

In Italy, the official student feedback survey, conducted by the university for every course and instructor, was very positive in comparison to other courses. In addition, interestingly, there was a major increase from the students' assessments to the question "at the beginning of this course, were you interested in the topics listed in the course description?" and their answers to the question "overall, are you satisfied with the lessons that was taught by the lecturer that you are evaluating?". Many students provided explanations in the open question for comments and suggestions to the teacher, and mentioned the team assignment as a "challenging effort that required a lot of time, but on the other hand was very rewarding". Some of the students also provided feedback for improvement, which can be summarized into the following three issues: (1) extend the duration of the assignment to enable deeper understanding of important sustainability challenges; (2) work with external stakeholders who will provide guidance and assessment; and (3) learn about real world solutions that are currently developed to respond to smart cities challenges.

In Israel, the official students' feedback at the end of the course was above the average, with high assessments for the questions related to levels of interest, clarity and organization of classes. Particularly, students provided comments on the involvement of the city representatives and mentioned that it gave them the understanding that this experience is much more than a course exercise and that their voice is heard by decision makers. Thus, they felt they can make an impact through this academic course. For them it was "the first academic course in which we actually went out of class to see how things are done and it contributed a lot to understand how decisions are made at top management level". Working directly with representatives of the municipality "enabled us to understand the complexity of initiating a new valuable project". It was "a very valuable experience thanks to the insights [we] gained by facing challenges that will make our life better".

The above reported two cases can be also assessed with regard to similar project management courses, which were delivered by the same instructor a year earlier in the same study programs. The overall courses' content and learning objectives were the same. In addition, also in the courses of 2018, the students were requested to work in teams to initiate and prepare a project plan with the aim to practice project management tools and techniques. However, in the previous run of courses, the students were free to select any challenge that they find interesting in order to provide a solution, while in the latter run of the courses they were clearly instructed to develop a new and innovative product or process for sustainable smart cities (more 
general in the first case, and more specific to a relevant city in the second case). For obvious reasons, the actual and specific assessments for each course are not presented here. However, comparing students' evaluations between 2018 to 2019 project management classes, in each one of the institutions, reveals increased values in all criteria, as shown in the following table.

TABLE 3

STUDENTS' ASSESSMENTS OF THE COURSES

\begin{tabular}{|lcc|}
\hline & Italian Uni. & Israeli Uni. \\
\cline { 2 - 3 } Overall satisfaction & $+7.8 \%$ & $+12 \%$ \\
\hline Learned skills & $+5.6 \%$ & $+6.3 \%$ \\
\hline Benefit of the experience & $+15.5 \%$ & $+18 \%$ \\
\hline Level of interest & $+5 \%$ & $+7.5 \%$ \\
\hline
\end{tabular}

\section{Content Analysis of Reflective Summaries}

Following the team work, at the end of the course, the students were requested to submit a reflective summary report to summarize their learning experience. As guidelines for the reflective summary, the following questions were presented: What did you learn? and How did you learn it? What was the most useful or meaningful things you learned in this course? What are the biggest achievements and improvements you made? What might/should be done in light of it? How will you connect the experience to further studies and actions? The submitted reports were analyzed using content analysis method to identify emerging themes (Hsieh \& Shannon, 2005; Krippendorff, 2018). The analysis of 80 summaries, was conducted using inductive reasoning to identify meaningful topics, following the four stages of (a) decontextualization - identifying and labeling each meaningful unit in the text with a code, based on open coding; (b) recontextualization -re-reading the texts while comparing to the final list of identified codes to verify that all the content has been reviewed in relation to the research aim; (c) grouping and categorization - creating homogeneous categories which represent themes that entails common meaning; and (d) compilation and abstraction - drawing conclusions to present a summary of themes emerged from the texts (Bengtsson, 2016; Elo \& Kyngäs, 2008). A list of concepts, each of them representing an array of words and terms that carry the same meaning in the context of the study, were identifies and categorized into 3 major categories, as presented in the following figure.

\section{FIGURE 2 \\ REFLECIVE SUMMARIES: MAIN THEMES}

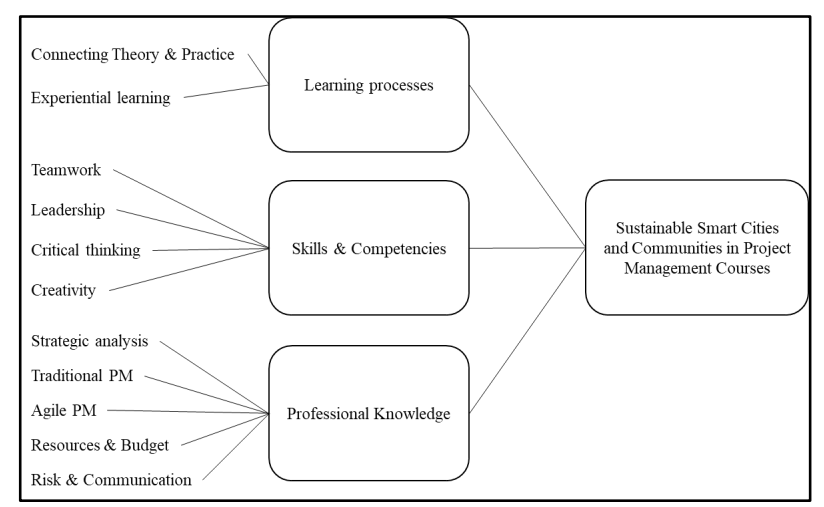

The three categories: learning processes, skills and competencies, and professional knowledge, summarize the array of insights that were presented by the students. The design and development of a project plan for one of the most important challenges the world is facing today "has been an experience 
that will be very useful at work in the future" as one of the students wrote. Although "it has been an enormous satisfaction seeing our idea growth from zero, [it was also] "sort of a 'puzzle' to understand the complexity and value of suggested ideas and plans" wrote another student.

\section{CONCLUSIONS}

Integrating real world challenges of sustainable smart cities and communities was found to be very valuable for project management students. They have clearly reflected on the added-value of working on significant challenges, which are relevant to their future in the context of sustainability. Furthermore, integrating actual current challenges, especially in a specific context and with an actual customer who is willing to adopt advantageous ideas and project plans and transform them into realized projects, increase students' level of interest, learned skills and overall satisfaction. With the growing understanding that "the choice for companies today is not if, but how, they should manage their sustainability activities" (Bonini $\&$ Swartz, 2014) and with the increased utilization of projects as a means to make a social, business and environmental impact (Marcelino-Sádaba et al., 2015), it is now the time to educate and train future project managers in this direction.

Sustainability is one of the most important challenges of our time. The world is moving towards a fourth industrial revolution where automation is substituting labor, the global society is even more interconnected, breakthroughs are exponentially growing and disruption is hitting systems of production, management, and governance (World Economic Forum, 2016). In this context, the world is facing ecological, social, and economic threats, that were only intensified since the outbreak of Covid-19. The triple bottom line, which was introduced by Elkington (2004) and is commonly named "the three Ps": people, planet and profit, provides a framework that sets the ground for effective response to sustainability challenges. While the project management studies in higher education have been evolved, in accordance to the profession, from the traditional concepts, mainly focused on construction and engineering, to technology and hightechnology implementations, mainly focused on software, communication and information technologies, and further developed to include advanced skills relevant to the dynamic environment (Seymour \& Hussein, 2014; Turner, 2016), it is the time to introduce sustainability concepts into this domain (Sankaran et al., 2020; Silvius \& Schipper, 2014a).

Initiating and planning a real project plan that responds to the Sustainable Development Goals (SDGs) has proven to be a valuable method that has an impact on both students' level of interest and motivation as well as learning the processes and tools for project initiation and planning. It is worthwhile to mention that from the educator point of view, preparing and delivering this type of academic course requires more efforts than a "standard" project management course, but the value that it carries is much higher for the instructor, for the students, and for the external "customer". Moreover, students learning through practical experience related to sustainability could have further long-term implications in their future jobs in organizations.

Based on the described cases and analysis, the following recommendations can be drawn: (1) introduce sustainability challenges in project management academic courses to increase awareness among students and increase their interest; (2) integrate real-world experiences, in the form of initiation and planning projects for sustainability challenges, to promote significant experiential learning; (3) engage external stakeholders who are interested in supporting advanced and innovative sustainability solutions to raise students' motivation for actual involvement and contribution. This paper demonstrates that nowadays project management curriculum should not only go beyond the traditional "iron triangle" to include additional aspects of project managers' skills and competencies, but it the responsibility of higher education institutions to educate and train the future project managers to make a difference with regard to sustainable world.

This study is not free from limitations. First, it is based on a limited set of data that derives from only two cases. Second, as an action research, it involves active participation of the researcher in the process. Third, it is not a rigorous study in the sense it cannot eliminate additional factors that may have been affected the results. However, as an explorative study on the topic of integrating sustainability into the classroom in higher education institutions, and specifically in the field of project management in business schools, this 
study highlights one of the most relevant and urgent themes that should be addressed nowadays. Further studies can build on the results presented here, either in a comprehensive study on the various methods and approaches to improve education and training of future sustainability responsible project managers, or by investigating the importance and impact of diverse sustainability goals in experiential project management academic courses. Therefore, there is a need for future studies, which will examine the contents or the methods of integrating sustainability into the curriculum of project management.

\section{REFERENCES}

Aarseth, W., Ahola, T., Aaltonen, K., Økland, A., \& Andersen, B. (2017). Project sustainability strategies: A systematic literature review. International Journal of Project Management, 35(6), 1071-1083.

Adriana, T-T., \& Ioana-Maria, D. (2013). Project success by integrating sustainability in project management. In Sustainability integration for effective project management (pp. 106-127). IGI Global.

Ardito, L., Ferraris, A., Petruzzelli, A.M., Bresciani, S., \& Del Giudice, M. (2019). The role of universities in the knowledge management of smart city projects. Technological Forecasting and Social Change, 142, 312-321.

Ashleigh, M., Ojiako, U., Chipulu, M., \& Wang, J.K. (2012). Critical learning themes in project management education: Implications for blended learning. International Journal of Project Management, 30(2), 153-161.

Avelar, A.B.A., da Silva-Oliveira, K.D., \& da Silva Pereira, R. (2019). Education for advancing the implementation of the Sustainable Development Goals: A systematic approach. The International Journal of Management Education, 17(3), 100322.

Bengtsson, M. (2016). How to plan and perform a qualitative study using content analysis. NursingPlus Open, 2, 8-14.

Bonini, S., \& Swartz, S. (2014). Profits with purpose: How organizing for sustainability can benefit the bottom line. McKinsey on Sustainability \& Resource Productivity, 2, 1-15.

Cicmil, S., \& Gaggiotti, H. (2018). Responsible forms of project management education: Theoretical plurality and reflective pedagogies. International Journal of Project Management, 36(1), 208218.

Dehler, G.E., \& Edmonds, R.K. (2006). Using action research to connect practice to learning: A course project for working management students. Journal of Management Education, 30(5), 636-669.

Eaton, A., \& Heckscher, C. (2020). COVID's Impacts on the Field of Labour and Employment Relations. Journal of Management Studies, 58(1), 275-279.

Egginton, B. (2012). Realising the benefits of investment in project management training: Evidence supporting the need for a more strategic approach. International Journal of Managing Projects in Business, 5(3), 508-527.

Elkington, J. (2004). Enter the triple bottom line. The Triple Bottom Line: Does It All Add Up, 11(12), 116.

Elo, S., \& Kyngäs, H. (2008). The qualitative content analysis process. Journal of Advanced Nursing, 62(1), 107-115.

Figueiró, P.S., \& Raufflet, E. (2015). Sustainability in higher education: A systematic review with focus on management education. Journal of Cleaner Production, 106, 22-33.

Hsieh, H-F., \& Shannon, S.E. (2005). Three approaches to qualitative content analysis. Qualitative Health Research, 15(9), 1277-1288.

Hussein, B.A. (2015). A blended learning approach to teaching project management: A model for active participation and involvement: Insights from Norway. Education Sciences, 5(2), 104-125.

Krippendorff, K. (2018). Content analysis: An introduction to its methodology (4th ed.). Sage publications.

Leal Filho, W., Simaens, A., Diaz, P.H., de Vasconcelos, C.R.P., Fritzens, B., \& Mac-lean, C. (2020). Integrating the Sustainable Development Goals into the strategy of Higher Education Institutions. 7th Responsible Management Education Research Conference. 
Lozano, R., Ceulemans, K., Alonso-Almeida, M., Huisingh, D., Lozano, F.J., Waas, T., . . Hugé, J. (2015). A review of commitment and implementation of sustainable development in higher education: Results from a worldwide survey. Journal of Cleaner Production, 108, 1-18.

Marcelino-Sádaba, S., González-Jaen, L.F., \& Pérez-Ezcurdia, A. (2015). Using project management as a way to sustainability. From a comprehensive review to a framework definition. Journal of Cleaner Production, 99, 1-16.

Mengel, T. (2008). Outcome-based project management education for emerging leaders-A case study of teaching and learning project management. International Journal of Project Management, 26(3), $275-285$.

Munasinghe, M. (1993). Environmental economics and sustainable development. The World Bank.

Ojiako, U., Ashleigh, M., Chipulu, M., \& Maguire, S. (2011). Learning and teaching challenges in project management. International Journal of Project Management, 29(3), 268-278.

Painter-Morland, M., Sabet, E., Molthan-Hill, P., Goworek, H., \& de Leeuw, S. (2016). Beyond the curriculum: Integrating sustainability into business schools. Journal of Business Ethics, 139(4), 737-754.

Raelin, J.A., \& Coghlan, D. (2006). Developing managers as learners and researchers: Using action learning and action research. Journal of Management Education, 30(5), 670-689.

Ramazani, J., \& Jergeas, G. (2015). Project managers and the journey from good to great: The benefits of investment in project management training and education. International Journal of Project Management, 33(1), 41-52.

Reason, P., \& Bradbury, H. (2001). Handbook of action research: Participative inquiry and practice. Sage.

Rogers, P.P., Jalal, K.F., \& Boyd, J.A. (2012). An introduction to sustainable development. Earthscan.

Sankaran, S., Müller, R., \& Drouin, N. (2020). Creating a 'sustainability sublime'to enable megaprojects to meet the United Nations sustainable development goals. Systems Research and Behavioral Science, 37(5), 813-826.

Seymour, T., \& Hussein, S. (2014). The history of project management. International Journal of Management \& Information Systems (IJMIS), 18(4), 233-240.

Shelley, A.W. (2015). Project management and leadership education facilitated as projects. International Journal of Managing Projects in Business, 8(3), 478-490.

Silvius, A.G., \& Schipper, P.R. (2014a). Sustainability in project management: A literature review and impact analysis. Social Business, 4(1), 63-96.

Silvius, A.J.G., \& Schipper, R.P.J. (2014b). Sustainability in project management competencies: Analyzing the competence gap of project managers. Journal of Human Resource and Sustainability Studies, 2(2), 46506.

Sroufe, R., \& Ramos, D. (2011). MBA program trends and best practices in teaching sustainability: Live project courses. Decision Sciences Journal of Innovative Education, 9(3), 349-369.

Sterling, S. (2004). Higher education, sustainability, and the role of systemic learning. In P.C.W.A.J.E. Blaze (Ed.), Higher education and the challenge of sustainability (pp. 49-70). Springer.

Svejvig, P., \& Andersen, P. (2015). Rethinking project management: A structured literature review with a critical look at the brave new world. International Journal of Project Management, 33(2), 278290.

Thomas, J., \& Mengel, T. (2008). Preparing project managers to deal with complexity-Advanced project management education. International Journal of Project Management, 26(3), 304-315.

Turner, M. (2016). Beyond the iron triangle: reflections of an early career academic. International Journal of Managing Projects in Business, 9(4), 892-902.

World Economic Forum. (2016). The Future of Jobs: Employment, Skills and Workforce Strategy for the Fourth Industrial Revolution. Retrieved from http://www3.weforum.org/\%0Adocs/WEF_Future_of_Jobs.pdf 